\title{
Lactic Acid Yield Using Different Bacterial Strains, Its Purification, and Polymerization through Ring-Opening Reactions
}

\author{
F. G. Orozco, ${ }^{1}$ A. Valadez-González, ${ }^{1}$ J. A. Domínguez-Maldonado, ${ }^{2}$ F. Zuluaga, ${ }^{3}$ \\ L. E. Figueroa-Oyosa, ${ }^{2}$ and L. M. Alzate-Gaviria ${ }^{2}$ \\ ${ }^{1}$ Materiales Unidades, Centro de Investigación Científica de Yucatán (CICY), Calle 40 No. 130, Colonia Chuburná de Hidalgo, \\ 97200 Mérida, YUC, Mexico \\ ${ }^{2}$ Renovables Unidad de Energía (CICY), Calle 40 No. 130, Colonia Chuburná de Hidalgo, 97200 Mérida, YUC, Mexico \\ ${ }^{3}$ Laboratorio de Polymer Group SIMERQO, Universidad del Valle, Ciudad Universitaria, Meléndez, 25360 Cali, \\ Valle del Cauca, Colombia
}

Correspondence should be addressed to L. M. Alzate-Gaviria; lag@cicy.mx

Received 19 September 2013; Revised 5 December 2013; Accepted 19 December 2013; Published 17 February 2014

Academic Editor: Peng He

Copyright (C) 2014 F. G. Orozco et al. This is an open access article distributed under the Creative Commons Attribution License, which permits unrestricted use, distribution, and reproduction in any medium, provided the original work is properly cited.

\begin{abstract}
Laboratory-scale anaerobic fermentation was performed to obtain lactic acid from lactose, using five lactic acid bacteria: Lactococcus lactis, Lactobacillus bulgaricus, L. delbrueckii, L. plantarum, and L. delbrueckii lactis. A yield of $0.99 \mathrm{~g}$ lactic acid/g lactose was obtained with $L$. delbrueckii, from which a final concentration of $80.95 \mathrm{~g} / \mathrm{L}$ aqueous solution was obtained through microfiltration, nanofiltration, and inverse osmosis membranes. The lactic acid was polymerized by means of ring-opening reactions (ROP) to obtain poly-DL-lactic acid (PDLLA), with a viscosity average molecular weight (Mv) of 19,264 g/mol.
\end{abstract}

\section{Introduction}

The quantity of nonbiodegradable plastic waste and the recycling of this waste pose increasing problems due to the loss of properties during each processing cycle, meaning that it is important to make products with biodegradable materials both in order to maintain basic needs and for waste processing.

A fully biodegradable polymer is a material that is converted to carbon dioxide, water, minerals, and biomass by organisms with no environmental impact or ecotoxicity [1]. Polylactic acid (PLA) is a biodegradable, biocompatible, and compostable polyester that can be used to manufacture biomedical scaffold implants and bone cements, surgical materials, and commercial disposable materials such as cups, plates, cutlery, and food containers. PLA possesses similar mechanical properties and processing conditions to polyethylene terephthalate (PET), polypropylene (PP), and polystyrene (PS) [2].
The monomer employed for PLA synthesis is lactic acid, which is a byproduct of anaerobic fermentation of an organic substrate transformed by microorganisms of the Lactobacillus genus [3]. Soccol et al. [4] reported that the most important isomer in the food industry is $L(+)$, given that it is the only one assimilated by humans through the production of the $L$ lactate dehydrogenase enzyme.

The yields obtained in different studies using lactic acid bacteria [5-12] are shown in Table 1.

Lactic acid exists in two enantiomeric forms, the $D(+)$ configuration and the naturally occurring $L(-)$ configuration. They produce the corresponding enantiomeric polymers by conservation of the chiral center. Commercial PLAs are also copolymers of $L$-lactide and $D$-lactide and their optical purity strongly affects their properties. Optically pure PLA is isotactic and highly crystalline. Decreasing the optical purity reduces the degree of stereoregularity and crystallinity. Poly $(L$-lactide $)$ with more than $15 \mathrm{~mol} \% D$-lactide is mostly amorphous [13]. 
TABLE 1: Yields obtained in different fermentation conditions using lactic acid bacteria.

\begin{tabular}{lcccc}
\hline LAB & System & $\mathrm{pH} / \mathrm{T}^{\circ} \mathrm{C}$ & Yield $^{*}$ & Reference \\
\hline $\begin{array}{l}\text { L. plantarum } \\
\text { L. helveticus }\end{array}$ & Batch & $6.0 / 35$ & 0.84 & {$[5]$} \\
$\begin{array}{l}\text { L. delbrueckii } \\
\text { lactis }\end{array}$ & Batch & $6.2 / 37$ & 0.96 & {$[7]$} \\
$\begin{array}{l}\text { L. delbrueckii } \\
\text { L. delbrueckii }\end{array}$ & Batch & $5 / 50$ & 0.92 & {$[8]$} \\
$\begin{array}{l}\text { lactis } \\
\text { Lactococcus }\end{array}$ & Batch & $5.5 / 42$ & 0.9 & {$[9]$} \\
$\begin{array}{l}\text { Lactis } \\
\text { L. bulgaricus }\end{array}$ & Batch & $6.0 / 38$ & 0.94 & {$[10]$} \\
L. plantarum & Batch & $5.5-6.0 / 38$ & 0.98 & {$[11]$} \\
\hline LAB: $6.4 / 42$ & 1.5 & {$[12]$} \\
\hline
\end{tabular}

LAB: lactic acid bacteria; $T$ : temperature; ${ }^{*}$ Yield (grams/gram) of lactic acid from lactose.

Monomer purity is important for polymerization to occur with good yields in terms of molecular weight and the desired characteristics for processing and application. A number of techniques have been employed in this vein, such as solvent extraction [14], ionic adsorption, direct distillation and membrane technology. The latter employs filtration systems and has proven fruitful in the fields of separation and concentration. It has numerous advantages over several traditional separation techniques, such as solvent extraction, adsorption and direct distillation. Furthermore, it offers greater energy efficiency and the high cost of solvents and adsorbents is not required in membrane separation, which allows for the possibility of concentrating organic compounds [15]. The technique for separating lactic acid by nanofiltration is a high-pressure solution diffusion mechanism and is suitable for molecules within the range of 50-500 Da. It produces monomers with purity levels of over $80 \%$ [16].

Lactic acid polymerization can be performed by means of opening the ring of the lactide, composed of two lactic acid molecules that form a ring in the presence of tin salts, heat, and vacuum [17]. ROP of lactones has been widely studied over the past 40 years. Carothers and coworkers explored this technique for lactones, anhydrides, and carbonates [18]. In the present day, the process for obtaining PLA via ROP employs polycondensation to obtain low molecular weight PLA, depolymerization to form the cyclic dimer (lactide), and ring-opening polymerization to obtain high molecular weight polylactic acid with tin(II) octoate or another organic stannous salt as a catalyst. As far as the polycondensation reaction is concerned, the prepolymer formed must have a molecular weight between 500 and $1000 \mathrm{Da}$, given that molecular weights below 500 do not favor the formation of the cyclic dimer, and molecular weights greater than 1000 lead to transport phenomena problems due to the increased viscosity [19].

The aim of this work was to compare the lactic acid yield from powdered milk using different lactic acid bacteria, its purification, through nanofiltration and inverse osmosis, and the synthesis of PDLLA using ring-opening polymerization.

\section{Material and Methods}

2.1. Substrate and Microorganisms. Lactose was obtained from powdered milk at concentration of $50 \mathrm{~g} / \mathrm{L}$.

The strains of $L$. delbrueckii lactis, $L$. plantarum, and $L$. delbrueckii were acquired from the National Collection of Microbial Strains and Cell Cultures of CINVESTAV, Mexico City, Mexico, and the strains of L. bulgaricus and Lactococcus lactis from Distribuidora Alcatraz, S.A. de C.V., Danisco brand.

2.2. Culture Medium. The culture medium used was rich in lactose, $15 \mathrm{~g}$ milk powder per $100 \mathrm{~mL}$ water, and MRS (Man, Rogosa, and Sharpe) agar. The growth curve was produced using threaded tubes with $10 \mathrm{~mL}$ of lactose broth for each strain in triplicate based on the McFarland scale at $600 \mathrm{~nm}$.

2.3. Fermentation. The fermentation broth was prepared from $15 \mathrm{~g}$ milk powder resuspended in $100 \mathrm{~mL}$ distilled water (equivalent to $50 \mathrm{~g} / \mathrm{L}$ lactose), enriched with yeast extract and $1 \%$ bacteriological peptone. The $\mathrm{pH}$ was adjusted with $4 \mathrm{~N} \mathrm{NaOH}$ to 6.0 for Lc. lactis, L. delbrueckii, and L. delbrueckii lactis, 6.5 for L. plantarum, and 5.5 for L. bulgaricus. The fermentation conditions were $38^{\circ} \mathrm{C}$ and $150 \mathrm{rpm}$ under $\mathrm{N}_{2}$ atmosphere.

2.4. Separation and Concentration. The fermentation broth was centrifuged at $400 \mathrm{rpm}$ and subsequently filtered in a 100 to $150 \mathrm{~mL} / \mathrm{min}$ cross flow cell. Microfiltration employed Whatman $0.22 \mu \mathrm{m}$ cellulose filter paper. Nanofiltration (NF) was performed with a NF-5 Sepro membrane under a 100 torr vacuum and reverse osmosis with a RO-4 membrane and 10 torr vacuum.

2.5. Ring-Opening Polymerization. PLA synthesis was carried out with the lactic acid obtained from the L. delbrueckii fermentation process using ROP polymerization. A temperature of $170^{\circ} \mathrm{C}$ and a 120 torr vacuum were applied for 3 hours for polycondensation. Once the product was weighed, $1 \%$ by weight anhydrous tin(II) chloride was added to produce lactide via inverse sublimation, with a temperature of $220^{\circ} \mathrm{C}$ and a 60 torr vacuum. The lactide was recrystallized in ethyl acetate five times at $70^{\circ} \mathrm{C}$ and stored in a vacuum desiccator for 24 hours [20]. Polymerization of the lactide was performed using tin octoate at $130^{\circ} \mathrm{C}$ for 24 hours.

2.6. Analysis. The growth curves were produced using a Jenway 6405 UV-Vis spectrophotometer.

Concentration and lactose consumption during fermentation were determined with the dinitrosalicylic acid (DNS) method [21]. The $D$ - and $L$-lactic acid yield and its concentration were estimated during fermentation with a Boehringer Mannheim/R-Biopharm enzymatic kit.

The polymer was characterized with Fourier Transform Infrared Spectroscopy (FTIR) using a Nicolet Protégé 460 Magna IR spectrophotometer. Molecular weight was determined by capillary viscometry using a Ubbelohde viscometer, with chloroform as solvent and a temperature of $25^{\circ} \mathrm{C}$ in accordance with ASTM Standard D2857 [22]. The glass 
TABLE 2: Production of $D$ - and $L$-lactic acid by bacterial strain.

\begin{tabular}{lccccc}
\hline$\left(\mathrm{g} \mathrm{L}^{-1}\right)$ & L. bulgaricus & Lc. lactis & L. plantarum & L. delbrueckii & L. delbrueckii lactis \\
\hline D-lactic & 12.35 & 15.40 & 23.87 & 23.44 & 33.42 \\
L-lactic & 15.55 & 14.89 & 22.11 & 27.49 & 7.60 \\
Concentration & 27.90 & 30.29 & 45.98 & 50.93 & 41.02 \\
Yield* $^{*}$ & 0.52 & 0.55 & 0.94 & 0.99 & 0.93 \\
\hline
\end{tabular}

${ }^{*}$ Yield (grams/gram) of lactic acid from lactose.

transition temperature $\left(T_{g}\right)$ was estimated via differential scanning calorimetry (DSC) using a PerkinElmer DSC-7 from 20 to $170^{\circ} \mathrm{C}$ with an increase of $2^{\circ} \mathrm{C} / \mathrm{min}$. The Nuclear Magnetic Resonance (NMR) analysis used ${ }^{1} \mathrm{H}$ and ${ }^{13} \mathrm{C}$ spectra in a Bruker apparatus with $\mathrm{CDCl}_{3}$ solvent at $400 \mathrm{MHz}$.

\section{Results and Discussion}

3.1. Lag and Exponential Phase (Data Not Shown). According to the linear regression of the McFarland scale, the $L$. delbrueckii lactis and Lc. lactis strains have a lag phase of less than 6 hours and the exponential phase extends up to 30 hours. Measurements showed no changes in absorbance from this time up to 48 hours. The bacteria are therefore assumed to have been in the stationary phase. Bai et al. [7] obtained growth curves with exponential phases of 20 hours for L. delbrueckii lactis in MRS medium and Nancib et al. [10] reported an exponential phase from 2 to 12 hours for Lc. lactis when fermenting date juice. These variations are due to the substrate type, given that simple sugars enter the metabolic pathway directly.

In the case of L. plantarum and L. bulgaricus, the lag phase was 5 hours and the exponential phase extended to 25 hours, from which time a stationary phase was observed. Brinques et al. [12] worked with lactose broth fermented by L. plantarum, which presented an exponential phase from the beginning of the fermentation up to 20 hours, whilst Welman and Maddox [23] used L. bulgaricus to ferment a lactose-rich medium and obtained an exponential phase from 8 to 20 hours.

L. delbrueckii presented a lag phase of 6 hours, exponential phase from 6 to 18 hours, and a stationary phase from 18 to 36 hours. This behavior was similar to that obtained by Kadam et al. [24], who used sugar cane juice and noted that this strain has greater metabolic activity, which favors its growth in less time.

3.2. Fermentation. The LAB Lc. lactis and L. bulgaricus consumed the lactose in 56 and $59 \mathrm{~h}$, respectively. Both were rejected due to the poor yield that they produced. $30.29 \mathrm{~g} / \mathrm{L}$ lactic acid (yield: $0.55 \mathrm{~g}$ lactic acid/g lactose) was obtained with $L c$. lactis and $27.90 \mathrm{~g} / \mathrm{L}$ lactic acid (yield: $0.52 \mathrm{~g}$ lactic acid/g lactose) for L. bulgaricus. This quantity was similar to that produced by lactobacilli when working with cultures mixed with $S$. thermophilus, as performed by Tanaka et al. [25] with a yield of $0.68 \mathrm{~g}$ lactic acid/g lactose and GueguimKana et al. [26] with a yield of $0.75 \mathrm{~g}$ lactic acid/g lactose. Both works exceeded the lactic acid concentration produced in this study, because the origin of mixed cultures can be
TABLE 3: Concentration of lactic acid by filtration processes.

\begin{tabular}{lccc}
\hline$\left(\mathrm{g} \mathrm{L}^{-1}\right)$ & MF & NF & RO \\
\hline$D$-Lactic acid & 23.34 & 31.15 & 38.23 \\
$L$-Lactic acid & 27.81 & 34.20 & 42.72 \\
Lactic acid & 51.15 & 65.35 & 80.95 \\
\hline
\end{tabular}

MF: microfiltration; NF: nanofiltration; RO: Reverse Osmosis.

an important factor in terms of the ability to perform lactic fermentation [27].

L. plantarum consumed the greatest quantity of lactose in $45 \mathrm{~h}$, with a lactic acid concentration of $45.98 \mathrm{~g} / \mathrm{L}$ (yield: $0.94 \mathrm{~g}$ lactic acid/g lactose). This behavior was similar to the L. delbrueckii strain, which produced $50.93 \mathrm{~g} / \mathrm{L}$ (yield: $0.99 \mathrm{~g}$ lactic acid/g lactose) in $48 \mathrm{~h}$. Both LAB presented similar fermentation times and substrate conversion to those reported by Brinques et al. [12], who worked with L. plantarum, and Kadam et al. [24] with $L$. delbrueckii, obtaining yields of 1.08 and $0.97 \mathrm{~g}$ lactic acid/g lactose, respectively, both in $48 \mathrm{~h}$.

Meanwhile, for L. delbrueckii lactis, the maximum lactose consumption time was $73 \mathrm{~h}$ to give a total of $41.02 \mathrm{~g} / \mathrm{L}$ lactic acid (yield: $0.93 \mathrm{~g}$ lactic acid/g lactose). Both Bai et al. [7], with a yield of $0.97 \mathrm{~g}$ lactic acid/g lactose, and Lee [9], with a yield of $0.70 \mathrm{~g}$ lactic acid/g lactose, performed fermentations in $100 \mathrm{~h}$.

Bozoglu and Ray [27] and Okano et al. [28] note that some LAB families are capable of producing one or other lactic acid isomer in greater concentrations. L. delbrueckii and $L$. delbrueckii lactis have a greater quantity of subtypes that produce almost entirely $L$-lactic acid and $D$-lactic acid, respectively, whilst the remaining $L A B$ used in this study produce a racemic mixture $(D, L$-lactic acid). Table 2 shows the lactic acid isomers produced by fermentation with the strains used in this study.

3.3. Separation and Concentration. Lactic acid, produced by L. delbrueckii, purification, and concentration was accomplished by means of microfiltration, nanofiltration, and inverse osmosis membranes. The changes in concentration for each step are shown in Table 3. The microfiltration process removed particles greater than $0.22 \mu \mathrm{m}$ in size, clarifying the fermentation broth. When the permeate passed through the nanofiltration membrane, it remained yellow in color but appeared more translucent. Milcent and Carrere [29] worked with microfiltration using a pore size of $0.1 \mu \mathrm{m}$ and achieved full microorganism retention, thereby clarifying the fermentation broth. The yellow coloration disappeared 
almost completely when using the reverse osmosis membrane, where the lactic acid remained in the residual liquid, whilst the salts were eliminated in the permeate. The final product had an oily consistency.

The nanofiltration process concentrated the lactic acid from 51.15 to $65.35 \mathrm{~g} / \mathrm{L}$, as shown in Table 3. Li et al. [30] reported an increase in lactic acid concentration from 54 to $70 \mathrm{~g} / \mathrm{L}$ based on filtration with a $200 \mathrm{Da}$ membrane. This study used $250 \mathrm{Da}$, which resulted in the lower acid concentration.

Membrane yield was calculated based on permeate flow (PF) using the following equation:

$$
\mathrm{PF}=\frac{\text { Permeate Volume }}{\text { Membrane Area } \times \text { Time }},
$$

expressed in $\mathrm{L} / \mathrm{m}^{2} \mathrm{~h}$.

For the nanofiltration membrane, the permeate volume was $10 \mathrm{~mL}$ in 5 hours. The PF can be increased, without affecting lactic acid recovery and concentration, by using a design that increases the membrane area and applying pressure, as performed by Jeantet et al. [31], who worked with a spiral design at a pressure of $4.0-6.0 \mathrm{MPa}$ and achieved $20 \mathrm{~L} / \mathrm{m}^{2} \mathrm{~h}$. Li et al. [30], meanwhile, used an area of $140 \mathrm{~cm}^{2}$ in a cross flow module at pressures of 7.0 $\mathrm{MPa}$ and obtained $37 \mathrm{~L} / \mathrm{m}^{2} \mathrm{~h}$. Lactic acid separation was not affected in either case and the recovery time was less than the one reported in this study.

A reverse osmosis membrane was employed into order to achieve a greater lactic acid concentration, resulting in $81 \mathrm{~g} / \mathrm{L}$ lactic acid. Li et al. [30] achieved 100\% lactic acid recovery using reverse osmosis membranes at a pressure of $5.5 \mathrm{MPa}$.

3.4. Ring-Opening Polymerization. Low molecular weight PLA was obtained from the lactic acid produced by fermentation with $L$. delbrueckii by means of direct condensation with the application of a vacuum (120 torr) and temperature $\left(170^{\circ} \mathrm{C}\right)$. The yield obtained was $51.44 \%$, producing a white, hygroscopic, and ductile oligomer. Lactide crystals were synthesized from the oligomer using $\mathrm{SnCl}_{2}$ as catalyst at $220^{\circ} \mathrm{C}$ and 60 torr. Then the lactide was ring-opening polymerized to synthetize PDLLA. The efficiency of this reaction was $1.8: 1$ lactide/PDLLA.

A sample was taken in each polymerization stage to perform FTIR (Figure 1), where the $-\mathrm{OH}$ bond stretching can be observed at wavenumber $3469 \mathrm{~cm}^{-1}$, the stretching vibration of the $-\mathrm{C}=\mathrm{O}$ bond at $1741 \mathrm{~cm}^{-1}$ and the $-\mathrm{C}-\mathrm{O}^{-}$ bond at $1392 \mathrm{~cm}^{-1}$, the asymmetric stretching vibration of the $-\mathrm{COO}^{-}$bond at $1593 \mathrm{~cm}^{-1}$, and the deformation of the $-\mathrm{OH}$ bonds at $1217 \mathrm{~cm}^{-1}$. We can also observe the $-\mathrm{C}-\mathrm{H}$ and $-\mathrm{CH}_{3}$ bond stretching present in the molecule at wavenumber $3000 \mathrm{~cm}^{-1}$ and the asymmetric bending deformation of the methyl group at $1452 \mathrm{~cm}^{-1}$. In comparison with the spectrum obtained from the oligomer synthesized from this lactic acid, it is possible to observe the appearance of the -C-O-C- bond, characterized by the signal at wavenumber $1174 \mathrm{~cm}^{-1}$, which shows that the lactic acid is polymerized by means of direct condensation reactions to form a polyester, as well as the disappearance of the $-\mathrm{C}-\mathrm{O}^{-}$at $1392 \mathrm{~cm}^{-1}$ that

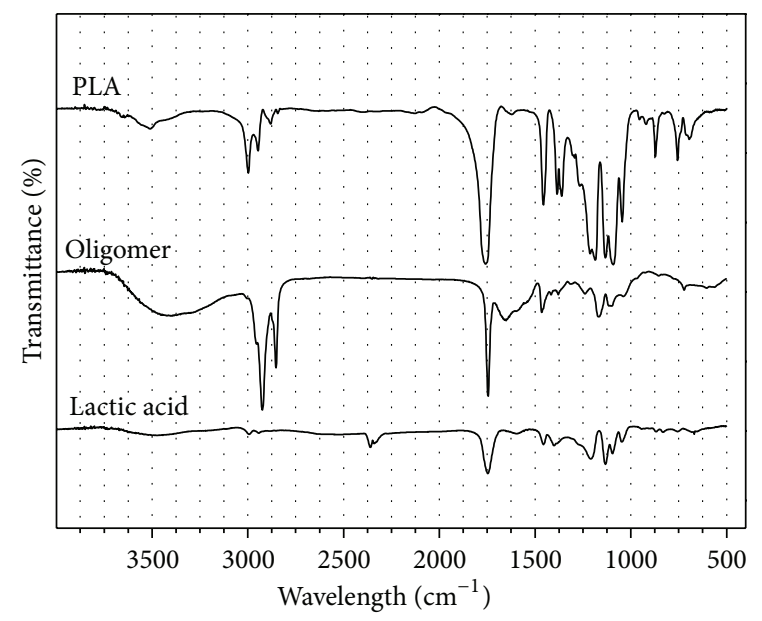

FIGURE 1: FTIR spectra of lactic acid produced by fermentation with L. delbrueckii and PLA synthesized.

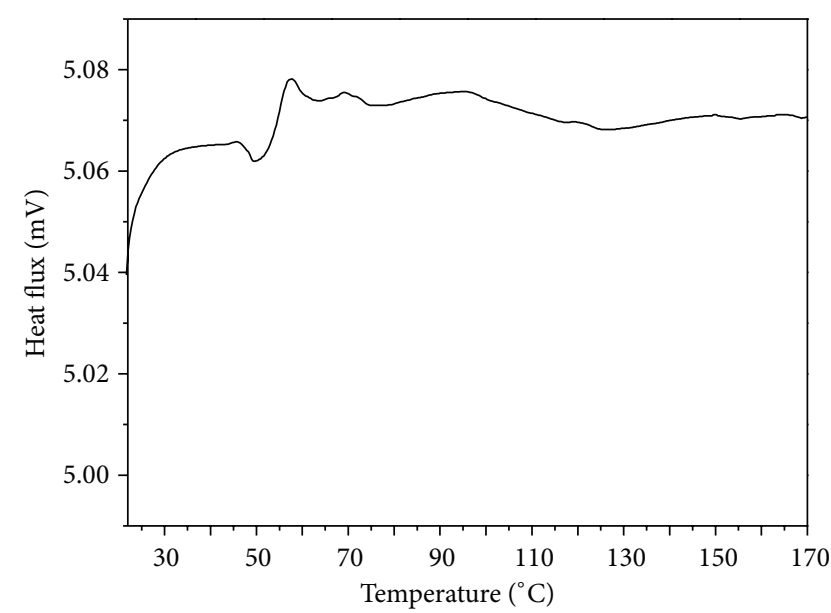

FIgURE 2: DSC curve of PDLLA synthesized, heated from 20 to $170^{\circ} \mathrm{C}$ at $2^{\circ} \mathrm{C} \mathrm{min}^{-1}$.

was present in the lactic acid. In the case of the PDLLA formed from the lactide, the FTIR spectrum clearly shows the asymmetric stretch of the polyester bond formed at wavenumber $1182 \mathrm{~cm}^{-1}$ and the deformation of the $-\mathrm{C}-\mathrm{O}$ bond at $1091 \mathrm{~cm}^{-1}$.

The intrinsic viscosity of the PLA was $30.028 \mathrm{~mL} / \mathrm{g}$. The Mark-Howink $K$ and $a$ constants used were of 0.0549 and 0.639 , respectively, values found by Jeantet et al. [31] on studying PLA for packing applications. The molecular weight was calculated from this value using the following equation: $[\eta]=K M^{a}$, to obtain an $\mathrm{Mv}$ of $19,264 \mathrm{~g} / \mathrm{mol}$. The presence of impurities that could not be removed by means of the RO process, water absorbed during a poor drying process or before polymerization, and which may be contained originally in the catalyst can affect lactide polymerization leading to a degradation of the polymer and interference during the ring-opening reaction, so preventing the molecular weight of the PLA from increasing. Brás et al. [32] have demonstrated this to be the case, and Kimura et 


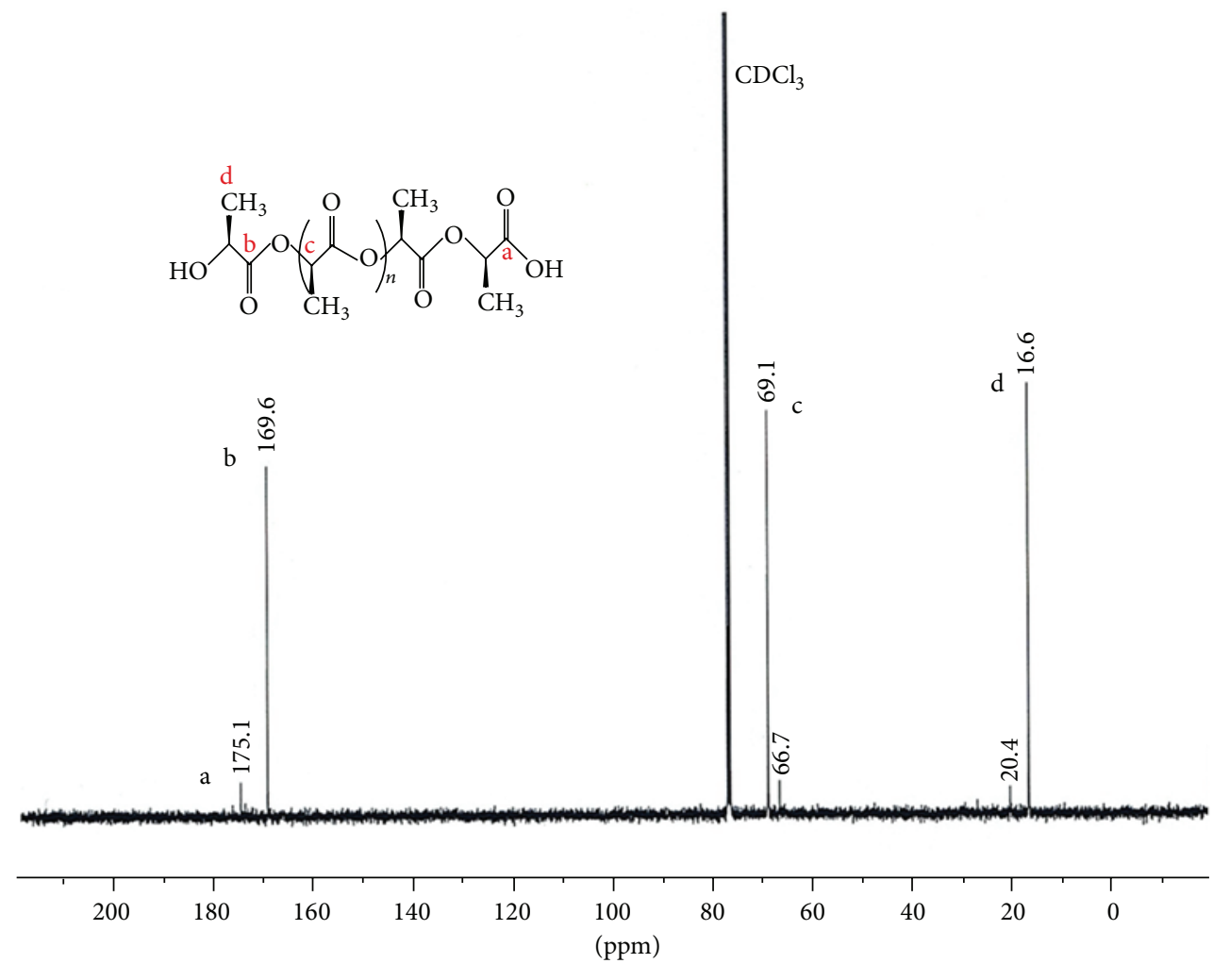

Figure 3: Spectrum ${ }^{13} \mathrm{C}-\mathrm{NMR}$ of PDLLA.

al. [33], among others, have shown that the water molecule produces hydrolysis of the polyester causing the bonds in the chains to break, thereby affecting molecular weight.

The glass transition temperature $T_{g}$ of the PDLLA obtained in this study by ring-opening was $54.34^{\circ} \mathrm{C}$. Figure 2 shows that the endothermic phase of the polymer lies between 50 and $58^{\circ} \mathrm{C}$ as it approaches its $T_{g}$. After this value, no changes occur in the material that indicate another material transition, confirming that the synthesized PDDLA is an amorphous polymer with a low molecular weight.

Stolt et al. [34] reported a molecular weight with an $\mathrm{Mn}$ number of $3500 \mathrm{~g} / \mathrm{mol}$ with a $T_{g}$ of $22^{\circ} \mathrm{C}$, whilst Zhao et al. [35] obtained a PDLLA with an $\mathrm{Mv}$ of $4,100 \mathrm{~g} / \mathrm{mol}$ and a $T_{g}$ of $48.17^{\circ} \mathrm{C}$. When the molecular weight of the PLA reached $33000 \mathrm{~g} / \mathrm{mol}$, the $T_{g}$ reported by Kim and Woo [36] was $59^{\circ} \mathrm{C}$. The glass transition temperature increased as the molecular weight increased. The $T_{g}$ reported in this study lies in the intermediate values compared to those reported in the literature and agrees with its molecular weight.

The ${ }^{13} \mathrm{C}-\mathrm{NMR}$ spectrum in Figure 3 allows us to corroborate the chemical structure of the PDLLA, where the signals at $\delta=16.6,69.1,169.6$, and $175.1 \mathrm{ppm}$ correspond to the $-\mathrm{CH}_{3}$, $-\mathrm{CH}-,-\mathrm{O}-\mathrm{C}=\mathrm{O}$, and $-\mathrm{COOH}$ groups, similar to the signals obtained by Chen et al. [37] when characterizing the structure of PLLA when polymerized by direct condensation with titanium(IV) butoxide as a catalyst. This causes racemization reactions in the $L$-lactic acid and signals similar to a PDLLA are obtained for the polymer. On the other hand, the signals match those obtained by Lei et al. [38], who performed a qualitative analysis of the chemical structure of PDLLA via this technique to confirm the results obtained by FTIR and ${ }^{1} \mathrm{H}-\mathrm{NMR}$.

The signals in the ${ }^{1} \mathrm{H}-\mathrm{NMR}$ spectrum in Figure 4 corroborate the chemical structure of the PDLLA with the doublet from 1.569 to $1.617 \mathrm{ppm}$ that corresponds to the hydrogen of the $-\mathrm{CH}_{3}$ group of the polymer body. The signals at $1.49 \mathrm{ppm}$ are the methyl terminals, whilst the quartet observed at $5.20 \mathrm{ppm}$ is characteristic of the hydrogen present in the $-\mathrm{CH}$ - of the polymer. The signals from 4.35 to 4.38 are from the $-\mathrm{CH}$ - terminals. The hydrogens of the hydroxyl group corresponding to the ends of the polymer chains is observed with the singlet at $3.89 \mathrm{ppm}$. These signals are very close to those reported by Lei et al. [38] and Konishi et al. [39], both of whom worked with PDLLA. In the first case, polycondensation was performed with a tin chloride catalyst, whilst the Konishi group used metal plates to observe the racemization behavior by determining the signal differences between PLLA and PDLLA.

\section{Conclusions}

The production of $D, L$-lactic acid in this study was performed by means of lactose fermentation using the L. delbrueckii strain with a yield of $0.99 \mathrm{~g}$ lactic acid/g lactose in a batch system for $48 \mathrm{~h}$. 


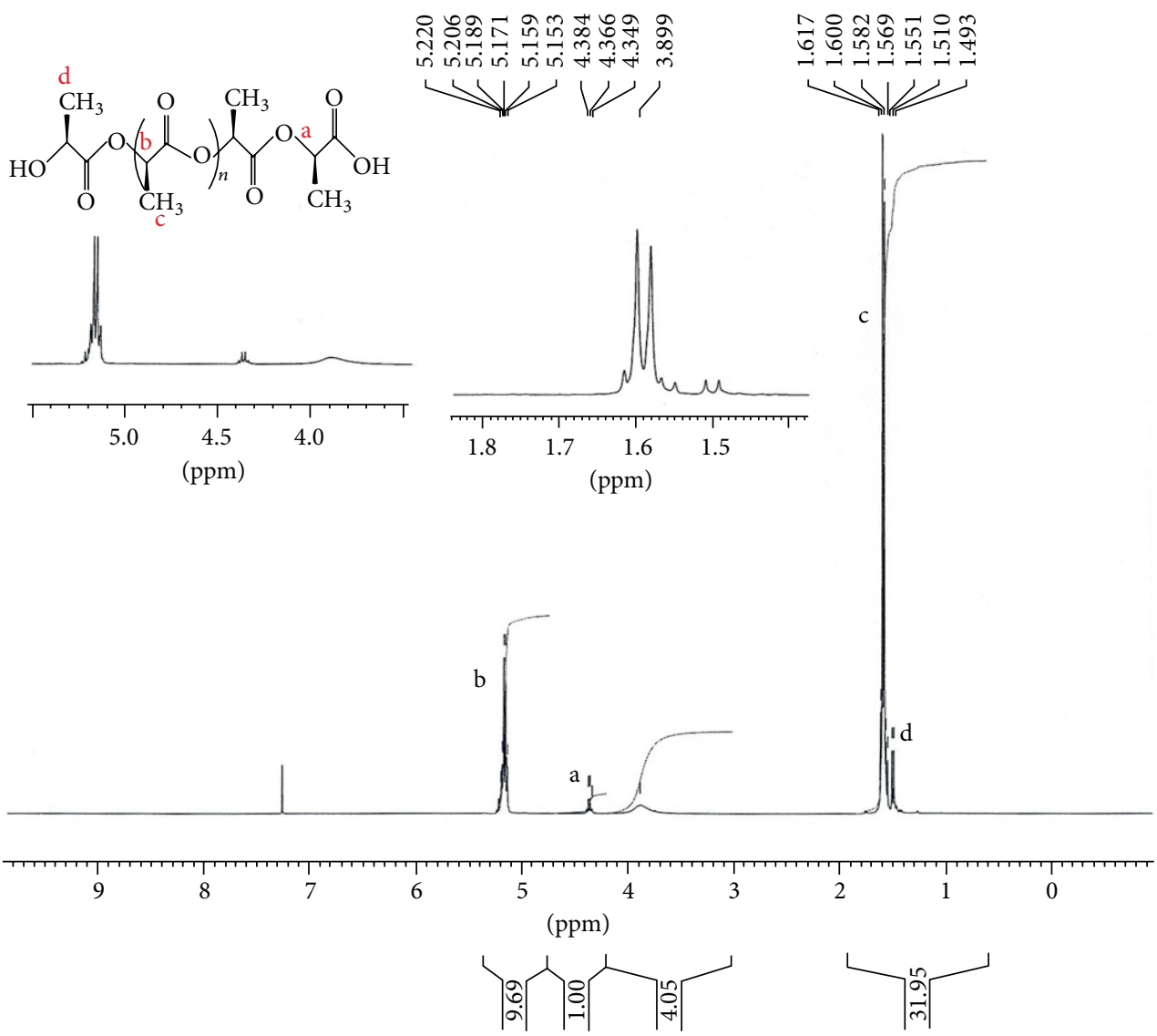

Figure 4: Spectrum ${ }^{1} \mathrm{H}-\mathrm{NMR}$ of PDLLA.

The lactic acid concentration in this study was $80.95 \mathrm{~g} / \mathrm{L}$, of which $38.23 \mathrm{~g} / \mathrm{L}$ corresponded to $D$-lactic acid and $42.72 \mathrm{~g} / \mathrm{L}$ to $L$-lactic acid, producing a translucent product with an oily consistency.

Lactic acid polymerization was performed with ringopening reactions to obtain PDLLA with a molecular weight Mv of $19,264 \mathrm{~g} / \mathrm{mol}$.

\section{Conflict of Interests}

The authors declare that there is no conflict of interests regarding the publication of this paper.

\section{References}

[1] J. M. Onyari, F. Mulaa, J. Muia, and P. Shiundu, "Biodegradability of poly(lactic acid), preparation and characterization of PLA/gum Arabic blends," Journal of Polymers and the Environment, vol. 16, no. 3, pp. 205-212, 2008.

[2] K. Mohanty, M. Misra, and L. T. Drzal, Eds., Natural Fibers, Biopolymers, and Biocomposites, CRC Press, Boca Raton, Fla, USA, 2005.

[3] M. Pelczar, L. Reid, and K. Chan, Microbiology, 1977.

[4] C. R. Soccol, V. I. Stonoga, and M. Raimbault, "Production of Llactic acid by Rhizopus species," World Journal of Microbiology and Biotechnology, vol. 10, no. 4, pp. 433-435, 1994.
[5] J. P. Guyot, M. Calderon, and J. Morlon-Guyot, "Effect of pH control on lactic acid fermentation of starch by Lactobacillus manihotivorans LMG 18010(T)," Journal of Applied Microbiology, vol. 88, no. 1, pp. 176-182, 2000.

[6] M. S. A. Tango and A. E. Ghaly, "A continuous lactic acid production system using an immobilized packed bed of Lactobacillus helveticus," Applied Microbiology and Biotechnology, vol. 58, no. 6, pp. 712-720, 2002.

[7] M. Bai, Q. Wei, Z. H. Yan, X. M. Zhao, X. G. Li, and S. M. $\mathrm{Xu}$, "Fed-batch fermentation of Lactobacillus lactis for hyperproduction of L-lactic acid," Biotechnology Letters, vol. 25, no. 21, pp. 1833-1835, 2003.

[8] X. Shen and L. Xia, "Lactic acid production from cellulosic waste by immobilized cells of Lactobacillus delbrueckii," World Journal of Microbiology and Biotechnology, vol. 22, no. 11, pp. 1109-1114, 2006.

[9] K. Lee, "Enhanced production of lactic acid by an adapted strain of Lactobacillus delbrueckii subsp. lactis," World Journal of Microbiology and Biotechnology, vol. 23, no. 9, pp. 1317-1320, 2007.

[10] A. Nancib, N. Nancib, and J. Boudrant, "Production of lactic acid from date juice extract with free cells of single and mixed cultures of Lactobacillus casei and Lactococcus lactis," World Journal of Microbiology and Biotechnology, vol. 25, no. 8, pp. 1423-1429, 2009.

[11] M. Ghasemi, G. Najafpour, M. Rahimnejad, P. A. Beigi, M. Sedighi, and B. Hashemiyeh, "Effect of different media on 
production of lactic acid from whey by Lactobacillus bulgaricus," African Journal of Biotechnology, vol. 8, no. 1, pp. 81-84, 2009.

[12] G. B. Brinques, M. C. Peralba, and M. A. Záchia, "Optimization of probiotic and lactic acid production by Lactobacillus plantarum in submerged bioreactor systems," Journal of Industrial Microbiology and Biotechnology, vol. 37, no. 2, pp. 205-212, 2010.

[13] L. Serna and S. Rodríguez, "Biotechnological production of lactic acid: state of the art," Ciencia y Tecnología Alimentaria, vol. 5, p. 54, 2005.

[14] S. A. Ataei and E. Vashegani-Farahani, "In situ separation of lactic acid from fermentation broth using ion exchange resins," Journal of Industrial Microbiology and Biotechnology, vol. 35, no. 11, pp. 1229-1233, 2008.

[15] K. W. Böddeker, Membrane Filtration, Springer, Berlin, Germany, 2008.

[16] A. Shahbazi and Y. B. Li, "Availability of crop residues as a sustainable feedstock for bioethanol production in North Carolina," Applied Biochemistry and Biotechnology, vol. 129, pp. 41-54, 2006.

[17] F. Achmad, K. Yamane, S. Quan, and T. Kokugan, "Synthesis of polylactic acid by direct polycondensation under vacuum without catalysts, solvents and initiators," Chemical Engineering Journal, vol. 151, no. 1-3, pp. 342-350, 2009.

[18] W. H. Carothers, G. L. Dorough, and F. J. Van Natta, "Studies of polymerization and ring formation. $\mathrm{X}$. The reversible polymerization of six-membered cyclic esters," Journal of the American Chemical Society, vol. 54, no. 2, pp. 761-772, 1932.

[19] K. Y. Dong, D. Kim, and S. L. Doo, "Synthesis of lactide from oligomeric PLA: effects of temperature, pressure, and catalyst," Macromolecular Research, vol. 14, no. 5, pp. 510-516, 2006.

[20] D. Fuentes, M. Díaz granados, and J. Perilla, "A method to obtain high purity Lactide by the depolymerization of Poly(Lactic Acid)," Revista Colombiana De Química, vol. 35, p. 115, 2006.

[21] G. L. Miller, "Use of dinitrosalicylic acid reagent for determination of reducing sugar," Analytical Chemistry, vol. 31, no. 3, pp. 426-428.

[22] "Standard Practice for dilute solution Viscosity of Polymers," ASTM D 2857, 2001.

[23] D. Welman and I. S. Maddox, "Fermentation performance of an exopolysaccharide-producing strain of Lactobacillus delbrueckii subsp. bulgaricus," Journal of Industrial Microbiology and Biotechnology, vol. 30, no. 11, pp. 661-668, 2003.

[24] S. R. Kadam, S. S. Patil, K. B. Bastawde, J. M. Khire, and D. V. Gokhale, "Strain improvement of Lactobacillus delbrueckii NCIM 2365 for lactic acid production," Process Biochemistry, vol. 41, no. 1, pp. 120-126, 2006.

[25] K. Tanaka, A. Komiyama, K. Sonomoto, A. Ishizaki, S. J. Hall, and P. F. Stanbury, "Two different pathways for D-xylose metabolism and the effect of xylose concentration on the yield coefficient of L-lactate in mixed-acid fermentation by the lactic acid bacterium Lactococcus lactis $\mathrm{IO}_{-1}$," Applied Microbiology and Biotechnology, vol. 60, no. 1-2, pp. 160-167, 2002.

[26] E. B. Gueguim-Kana, J. K. Oloke, A. Lateef, and M. G. ZebazeKana, "Novel optimal temperature profile for acidification process of Lactobacillus bulgaricus and Streptococcus thermophilus in yoghurt fermentation using artificial neural network and genetic algorithm," Journal of Industrial Microbiology and Biotechnology, vol. 34, no. 7, pp. 491-496, 2007.

[27] T. F. Bozoglu and B. Ray, Lactic Acid Bacteria: Current Advances in Metabolism, Genetics and Applications, Springer, New York, NY, USA, 1996.
[28] K. Okano, T. Tanaka, C. Ogino, H. Fukuda, and A. Kondo, "Biotechnological production of enantiomeric pure lactic acid from renewable resources: recent achievements, perspectives, and limits," Applied Microbiology and Biotechnology, vol. 85, no. 3, pp. 413-423, 2010.

[29] S. Milcent and H. Carrere, "Clarification of lactic acid fermentation broths," Separation and Purification Technology, vol. 22-23, pp. 393-401, 2001.

[30] Y. Li, A. Shahbazi, K. Williams, and C. Wan, "Separate and concentrate lactic acid using combination of nanofiltration and reverse osmosis membranes," Applied Biochemistry and Biotechnology, vol. 147, no. 1-3, pp. 1-9, 2008.

[31] R. Jeantet, J. L. Malubois, and P. Boyaval, "Semicontinuous production of lactic acid in a bioreactor coupled with nanofiltration membranes," Enzyme and Microbial Technology, vol. 19, no. 8, pp. 614-619, 1996.

[32] R. Brás, M. T. Viciosa, M. Dionísio, and J. F. Mano, "Water effect in the thermal and molecular dynamics behavior of poly $(\mathrm{L}-$ lactic acid)," Journal of Thermal Analysis and Calorimetry, vol. 88, no. 2, pp. 425-429, 2007.

[33] T. Kimura, N. Ihara, Y. Ishida, Y. Saito, and N. Shimizu, "Hydrolysis characteristics of biodegradable plastic (poly lactic acid)," Journal of the Japanese Society for Food Science and Technology, vol. 49, no. 9, pp. 598-604, 2002.

[34] M. Stolt, M. Viljanmaa, A. Södergard, and P. Törmälä, "Blends of poly ( $\varepsilon$-caprolactone-b-lactic acid) and poly(lactic acid) for hot-melt applications," Journal of Applied Polymer Science, vol. 91, no. 1, pp. 196-204, 2004.

[35] Y. Zhao, Z. Wang, J. Wang, H. Mai, B. Yan, and F. Yang, "Direct synthesis of poly(D,L-lactic acid) by melt polycondensation and its application in drug delivery," Journal of Applied Polymer Science, vol. 91, no. 4, pp. 2143-2150, 2004.

[36] K. W. Kim and S. I. Woo, "Synthesis of high-molecular-weight poly(L-lactic acid) by direct polycondensation," Macromolecular Chemistry and Physics, vol. 203, no. 15, pp. 2245-2250, 2002.

[37] X. Chen, H. S. Kim, E. S. Kim, and J. S. Yoon, "Synthesis of high-molecular-weight poly(l-lactic acid) through the direct condensation polymerization of L-lactic acid in bulk state," European Polymer Journal, vol. 42, pp. 468-472, 2006.

[38] Z. Q. Lei, S. F. Wang, and Y. B. Bai, "Synthesis of high-molecularweight poly(lactic acid) from aqueous lactic acid cocatalyzed by $\varepsilon$-caprolactam and tin(II) chloride dihydrate," Journal of Applied Polymer Science, vol. 105, no. 6, pp. 3597-3601, 2007.

[39] S. Konishi, T. Yokoi, B. Ochiai, and T. Endo, "Effect of metal triflates on direct polycondensation of lactic acid," Polymer Bulletin, vol. 64, no. 5, pp. 435-443, 2010. 

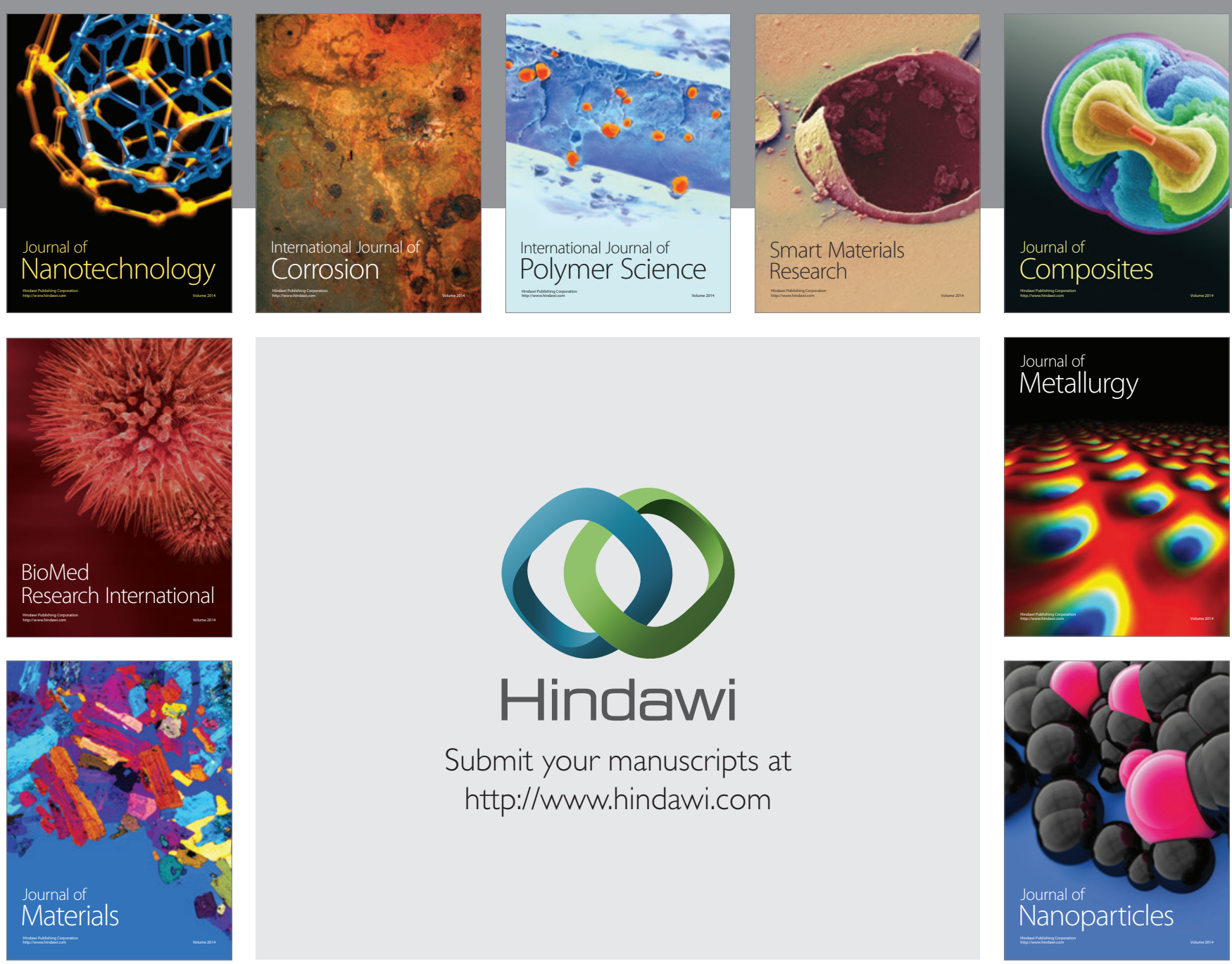

Submit your manuscripts at http://www.hindawi.com
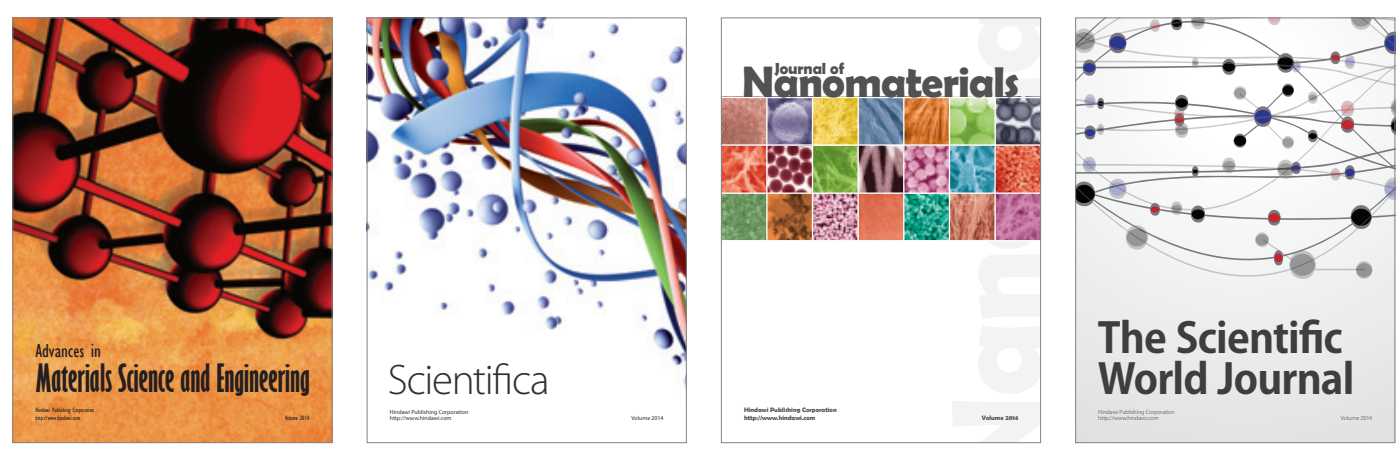

\section{The Scientific World Journal}
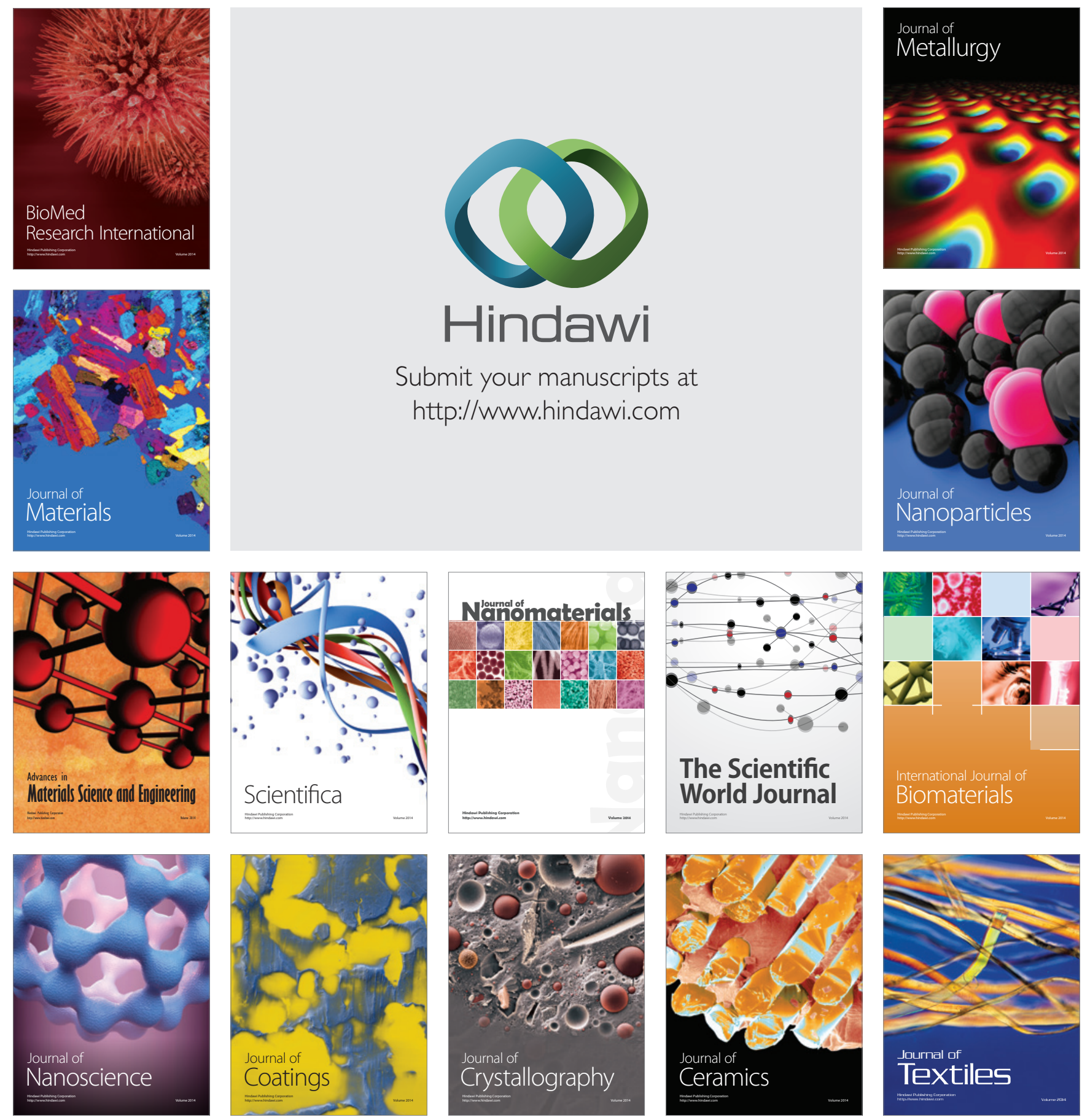